\title{
The relevance of Rumi and his work in contemporary society
}

\author{
Hanzala Mojibi \\ hani.mojibi@gmail.com \\ Student, New Delhi, India
}

\begin{abstract}
Life and work of Mawlana Rumi who has left an abundant source of divine knowledge for generations to take advantage of.
\end{abstract}

Published by IJRP.ORG. Selection and/or peer-review under responsibility of International Journal of Research Publications (IJRP.ORG)

\section{Rumi: A Sketch}

Jalal ad-Din Muhammad Balkhi, widely known as Mawlana Rumi or simply Rumi, was a 13th Century figure acclaimed for being a poet, scholar, jurist and Sufi mystic. Born on 30th September 1207, his words and influence still linger in the modern world. Names were usually an indication of a person's lineage or native place. Rumi was born in Balkh, current day Afghanistan, hence the title Balkhi. Born in a family of esteemed theologians, Rumi had his thoughts shaped from a young age. His father was Baha ud-Din Walad, himself a revered theologian, jurist and Sufi mystic. In fact his grandfather was one too. Coming from a family of Sufi legacy, Rumi is said to be a descendant of Caliph Abu Bakr. His mother was Mumina Khatun, a simple and virtuous lady from a family of learned Islamic scholars. Upon the invasion of Afghanistan by the Mongols, Rumi had to leave his place of birth, Balkh, with his family and shift to Konya, Turkey when he was only 9 years old. Rumi, thus, could also be termed as a refugee, the relevance of which will be revealed later on. The migrating carvan of him and his entire family travelled in the Middle East lands including Baghdad, Malatya, Damascus, Erzincan, Kayseri, Nigde and Sivas. After a final trip to Makkah, Saudi Arabia to perform the annual pilgrimage, they finally settled in Konya, Turkey. Rumi married Gowhar Khatun in 1225 with whom he had two sons, Sultan Walad and Alaeddin Chalabi. Upon her death, he married again having one son, Amir Alim Chalabi and one daughter, Malakeh Khatun. In one of his journeys through the Middle East he met one of the most famous Persian poet, Attar. Of him, Rumi once said, "Attar has traversed the seven cities of love, 
we are still at the turn of one street". Attar saw a spiritual zeal in him and watching his father walking ahead him, said, "Here comes a sea followed by an ocean".

Baha ud-Din, his father, became the head of a religious school and upon his death, Rumi took on the position as an Islamic Mawlana. For 9 years, he practised Sufism as a disciple of his father's student, Sayyed Burhan ud-Din Muhaqqiq Termazi. He acquired a lot of knowledge about spirituality. Then began Rumi's public life, him issuing fatwas and giving sermons in the mosques of Konya. He was also an Islamic teacher and taught in such a religious school.

His ethereal legacy had an impact on lands beyond his borders or ethnic originality. His life was appreciated amongst Iranians, Tajiks, Turks, Greeks and other Central Asian Muslims. Later, when his work was translated, he became an icon of spirituality around the world also being named as 'most popular poet' in the United States. Some of the languages his work has been translated into are German, Turkish, Arabic, Urdu, Italian, Spanish, Russian and English.

Essentially Rumi's work was written in Persian but he also used Turkish, Arabic and Greek in his writings. His infamous 'Mathnawi' is considered the greatest poem in the Persian language. His poetry has directly influenced many literatures around Central Asia like Persian, Turkish, Ottoman, Azerbaijani, Iranian, Urdu and Pashto.

\subsection{Meeting with Shams Tabrizi}

Shams-i-Tabrizi, born Shams al-Din Mohammad, was a wandering thinker and philosopher who weaved baskets and sold girdles for a living. He received his education in Tabriz, his master being Baba Kamal al-Din Jumdi.

On 15th November 1244, Shams Tabrizi came to the Sugar Merchants on Konya dressed all in black looking for something he knew he would find there. Eventually, he found Rumi riding a horse surrounded by his disciples, having just given a class. Shams caught hold of the reins of the horse, abruptly and rudely asking him, "Who was the greater mystic, Abu Yazid Bistami or Prophet Muhammad?"

Rumi felt Shams look deep into his eyes, causing rivers of heightened emotions flow within his body. "The Prophet Muhammad was greater" replied Rumi.

Shams then said, "Did not the Prophet say, 'we have not known Thee as Thou deserve to be known' while Abu Yazid exclaimed, 'How great is my glory, I am exalted, my dignity is unpraised."'

Mawlana explained that Prophet Muhammad was the greater of the two as the Prophet's capacity for God was unlimited; his desire was endless and he was always thirsty. While Bayazid was filled to capacity by a single experience of divine blessing. With every moment Prophet Muhammad came closer to God, he regretted his previous distant state.

It is said that upon this answer both men fell and cried out. Shams, in awe of finding that which he longed for, and Rumi under the weight of an unprecedented power. They embraced and developed a love for the sake the divine that shall be remembered for all the time to come.

This is one of the few accounts present of their first meeting which kindled a fire in Rumi that was never seen before. As of Shams, he found his life's purpose in guiding and mentoring the esteemed man. In all of the accounts, the men find in each other something they were looking for but didn't even know it. 
The two men, lost in God's consciousness spent 40 days closed behind doors. They explored what was called awakening and experienced the ecstasy spoken of by the Sufis. The time they spent there, rapt in God's enlightenment changed both of them in wondrous ways. Rumi became a casting full of God's love. Shams, on seeing this, opened the doors.

Rumi was a changed man, thereafter. From an accomplished teacher and learned jurist, he became an ascetic, preaching God's love in poetic form and ecstatic mood. He swayed and roamed like a lover does for a new found beloved. He begot an unknown and an unimaginable joy by telling people of this love and getting people acquainted with the love of God that he was enjoying.

Some lowly people have tried to demean the Mawlana's image by trying to establish a wrong relationship between him and Shams Tabrizi. But men of honet and pure virtue like him are rare to find. These men held a love for the path of God that they were upon. One was the teacher while the other the student. Although the student way outpaced the teacher in spiritual grasp and the knowledge of the unseen, his involvement remains monumental. The two had a very strong and deep connection but it was never in an ill manner or motive. They were companions in the seeking of God and his true sense of being.

\subsection{Rumi's Works}

Rumi began writing henceforth, of ethereal devotion and an unthinkable bond between man and the Omnipotent. But there came an incident that deeply affected Rumi; the disappearance of Shams. It was on 5th December 1248 that Rumi last saw his closest friend, Shams. It is hugely rumoured that he was murdered by one of Rumi's son, Ala Ud-Din who is said to have been jealous of the extremely close and deep relationship of his father and Shams. When Shams Tabrizi was in search of company of 'the one', he had heard a voice say, "And what will you give up for it?" "My head!" he had replied. Indeed, he gave his head for the company of the one he sought all his life.

Rumi was left bereft and struck with enormous pain. In Shams he saw a partner who understood God and his true understanding in a way that none other could. Although unknown how, Shams helped Rumi the most in finding the path of divinity of the unconscious. His loss was felt heavily upon him. He took to seclusion and alienation. Writing of his departure Rumi says,

"You left and I cried tears of blood. My sorrow grows. It's not just that you left. But when you left, my eyes went with you. Now how will I cry?"

In honour of his friend that he so admired, Rumi wrote 'Diwan-e-Shams-e-Tabrizi' also known as 'Diwan-eKabir'. It is a book composed of lyrical poetry of about 40000 and more verses. It is easily considered to be one of the best works in Persian.

Although 'Diwan-e-Shams-e-Tabrizi' received much acclaim, Rumi's greatest work remains the enormous 6 volume 'Masnavi-e-Manavi'. It is a Persian language extensive poem. Considered to be the most important work of Sufism, it is a series of 6 books of didactic verses strung together. It is enlightening in nature, teaching people the way to achieve God's true love in an undiluted way.

\subsection{Rumi as an Influence}


Through the ages, starting from the Middle East, Rumi has influenced and shaped thousands of lives. It was in relatively recent times that the West discovered the charm of the entranced poet. Living his life, after the disappearance of Shams, as a poet calling people to the utmost joy that he had found in God's company, Rumi wrote philosophical lines that were profound even to the men not of his religion. Today, his work has been translated in many a language and has been studied deeply by many.

The West lost itself in its monstrous economic greed and worldly affairs, so much so that spirituality and the callings of the soul was set to no importance. After centuries of the blind race, some discovered the void in their lives. They had money and luxuries but not a satisfaction that they aimed for. They fed their bodies yet their soul remained hungry. It was in such a search of higher knowledge and seeking the truth that Rumi comes and says,

"I looked in temples, churches and mosques. But I found the Divine within my heart."

Rumi's popularity skyrocketed with his translations being sold out through the world. His words were of such truth that it moved people. He quickly became and remained the most popular and bestselling poet in all of the US.

There have been innumerous researches and studies on the colossal, in depth, works of the Mawlana but perhaps more are needed still for he spoke of a love known not to man by now.

Rumi's translated poetry has been used by stars like Madonna, Demi Moore and Martin Sheen. Recorded versions of his poetry have gone up to Billboard's Top 20 list. Many monumental figures have quoted him. His recitations are played at Donna Karen's fashion shows. Several films about him and his life are in the works one of which involves Leonardo DiCaprio, the academy award winning actor, to be the main lead.

One of the main reasons Rumi appeals to such a huge audience is because of his direct approach to Godliness and oneness with that higher authority. He writes,

"Come, come, whoever you are,

Wanderer, idolater, worshiper of fire,

Come even though you have broken your vows a thousand times,

Come, and come yet again.

Ours is not a caravan of despair."

He, although a devout Muslim and Islamic scholar, in his spiritual understanding includes people of all faith in seeking God. This understanding and inclusion of people from all spheres has perhaps been instrumental in his fame and reverence.

Rumi emphasises on a person's personal relation with the Divine himself rather than through someone else. No matter how lowly a person may feel he is, they can always find the love of God deep in them, he believed. A person's position is not to be determined by his stature but his closeness to the Divine. 


\subsection{Rumi and his Misinterpretations}

Although a devout Muslim and Islamic scholar, his writing and his life often reflected that which isn't permissible in Islam. It has amounted to controversy and debate. Rumi once said, "Either give me more wine or leave me alone."

This is just one of the many instances that Rumi has used intoxication in his poetry. And although the usage of being drunk on emotions is a common phrase or technique to depict the intricate thoughts of the writer, it is interesting to note the fact that he was writing in the 13th century, using his words brilliantly to portray his inner feelings. Rumi talked not of being drunk in the sense that we know of today but of his unexplainable love for Divinity and the pleasure he derived from it.

Rumi also used to play music, his favourite instrument being the Ney (reed flute). Some scholars have seen this as a transgression of Islamic law. But he was a Sufi of his own kind. He was the one who found oneness with God in all ways possible. His music was such that it entrapped his soul into a dance that we can't understand maybe. And all his life, his mannerism was that of a hermit, free from indulgence yet full of enlightenment.

He practised what is called 'Tasawwuf'. It is a religious branch of Islam that is of much higher spiritual position than any. But not many can achieve true levels of it. It requires the purification of the soul from lowly human characteristics of malice, hate, scorn etc. It wants the soul to be set free. For only when the soul is set free can it reach its true calling. Rumi was not a typical poet or writer, he wrote something of much higher understanding than what we normally do. His were words of such wisdom that they fail not to shake the hardest of hearts.

\subsection{Deriving Lessons from Rumi's Works}

Rumi wrote of things we indulged in and left a morality check for us to ponder upon. His poetry wants you to question and seek the truth that you know of. He wants you to set your soul free from the normalcy of human behaviour and see what it truly is for. Hi words touch us on a depth that others fail to do so, because his weren't words written merely by hand; his were words written by soul. A soul so pure and pristine that we still wonder of the true stature of the Mawlana.

He comments on various ills of the society and condemns them in a subtle way. In the Masnavi Manavi, he has strung together many short stories from which morals can be derived. His stories in fact have become so common and popular that some haven't even been accredited to him anymore.

A story that has been adapted in many languages and ways goes like this.

"A philosopher, a mathematician and a poet were walking along a beach. They decide to go for a ride on a boat for leisure. In the middle of the ride, they get bored so decide to tease the boatman. The philosopher asks, "So... Have you studied any philosophy or simply row all day?"

“No sir, I haven’t studied any philosophy” he replied.

"Shame. You've wasted 1/3rd of your life"

"Say, have you any idea of mathematics?" the mathematician asked next. 
"No sir, I have none" the boatman says.

"Shame. You've wasted 1/3rd of your life"

"Do you write by any means?" the poet taunted.

"I'm afraid not" the boatman replied.

"Shame. You've wasted 1/3rd of your life"

The group goes on when suddenly a storm forms in the ocean and shakes the boat. The boatman foresees a huge wave and asks, "My sirs, does any of you swim?"

"We don't!" they replied.

"I'm sorry but you've wasted your whole lives" the boatman said and jumped into the water to swim ashore."

These are the kind of simple yet witty stories that had a moral in them. From simply pride to vanity, this story gives us several morals. Such pieces frequently appear in his book when he isn't talking about a love so philosophical and strong that few have been able to understand it.

\subsection{Conclusion}

Rumi was not a writer in his natural form; he was a lover. A lover who called upon one and all to love. His were words of bringing people together to bask in the eternal love of the Divine. He calls upon people of all faiths and beliefs. His words don't discriminate. His wisdom doesn't divide. He told us to steer clear off of material life and a sense of oneness with this world and rather focus on connection with the higher power or authority.

In a world so full of hate and divide, we need men like him to guide us to the truth. A world where materialism and possession has overtaken humanity and emotions, Rumi takes us back and reconnects us to what makes us the best of all creations.

Sadly still, he is but many centuries gone now. But his words live on. We must bank upon them and seek guidance from them. The pure love that he spoke of, the divinity that he experienced and the depth of his spiritual zeal.

We may tend to the wanting of the body, but as beings with a soul, we always crave for that which fills our inner being. Rumi is the cup bearer that quenches the thirst of the soul. Not only that, he then shows us the way to the river itself.

\section{References}

Rumi, Jalaluddin. The Essential Rumi. Tl. Coleman Barks. Harper Collins, 2004

Translations from Diwan e Shams. Tl. Shahriari, Shahriar. Vancouver, 1982 
Mohammed, Hakeem. Maarife Mathnavi. Kutub Khana Mazhari, 1972

\section{"Rumi" Wikipedia}

Ali, Rozina “The Erasure of Islam from Rumi’s Poetry” The New Yorker Web. 5 Jan 2017

Gander, Kashmira “Who is Rumi?” The Independent Web. 27 June 2016

Ciabattari, Jane "Why is Rumi the best-selling poet in the US?" The BBC Web. 21 Oct 2014 